\title{
Prevalensi Mikrofilaria pada Nyamuk Culex dan Manusia di Desa Dukuhturi, Kecamatan Bumiayu, Kabupaten Brebes
}

\author{
Khairina Dewi Handayani ${ }^{1}$, Endang Srimurni Kusmintarsih ${ }^{2}$, Edy Riwidiharso ${ }^{3}$ \\ Fakultas Biologi Universitas Jenderal Soedirman Purwokerto \\ email : khairinadewi14@gmail.com
}

\begin{abstract}
Lymphatic filariasis or elephantiasis is a vector borne disease caused by filarial worms that live in the lymph glands and lymph vessels of humans. W. bancrofti is the highest infection (90\%) in the world. In urban areas, filariasis bancrofti was transmitted by Culex mosquitoes. Based on the health databases province, the number of people with filariasis in Central Java from 2011 to 2014 did not decline the cases. Based on the health profile of Regency / City in 2014, there are 23 cases of filariasis in Brebes regency, Central Java. One of the filariasis cases were found in the village of Dukuhturi, Bumiayu sub- district, Brebes. The survey of filariasis in Dukuhturi has never been done previously, therefore, this research conducted to observe of the biology of its vector and infection of filariasis in community. Culex sp. can be potentially as a vector is stated in many things, such as if was found microfilariae in the mosquito and the mosquito everbeen bite of the humans blood, it can be detected by the parousity mosquito in its ovaries. The aims of this research are to determine the parity rate of the mosquito, the prevalence of mosquitoes and villagers Dukuhturi were infected by microfilariae, and the density of microfilariae in respondents who infected by microfilariae. This research was conducted by using a survey method with cluster random sampling. Blood sampling performed by the ethical clearance and informed concent. The data were tabulated and analyzed descriptively based parousity of mosquitoes, the prevalence of mosquitoes and human who infected by microfilariae, and density of microfilariae in the human who infected by microfilariae. The result shows that parousity of mosquito Culex $\mathrm{sp}$. is high $(94,45 \%)$ but the prevalence either in mosquito and respondent were $0 \%$, so that the density of microfilariae is 0 .
\end{abstract}

Keyword: filariasis, parousity, prevalence, dencity of microfilariae.

\begin{abstract}
Abstrak
Filariasis limfatik atau penyakit kaki gajah merupakan salah satu penyakit tular vektor yang disebabkan oleh cacing filaria yang hidup dalam kelenjar limfa dan saluran limfa manusia. Filariasis limfatik yang disebabkan Wuchereria bancrofti mendominasi hampir $90 \%$ infeksi di dunia.Di daerah perkotaan, filariasis bancrofti ditularkan oleh nyamuk Culex.Berdasarkan database kesehatan per Provinsi, jumlah penderita filariasis di Jawa Tegah dari tahun 2011 sampai 2014 tidak mengalami penurunan. Berdasarkan Profil kesehatan Kab/Kota 2014, di Kabupaten Brebes terdapat 23 kasus filariasis.Salah satu kasus filariasis tersebut ditemukan di Desa Dukuhturi, Kecamatan Bumiayu, Kabupaten Brebes yang kemungkinan ditularkan oleh nyamuk Culex sp. Survei mengenai filariasis belum pernah dilakukan di desa tersebut, oleh karena itu dilakukan survei terhadap darah tepi penduduk Desa Dukuhturi dan nyamuk Culex sp. sebagai vektornya. Nyamuk Culex sp. dapat berpotensi sebagai vektor filariasis jika ditemukan mikrofilaria di dalam tubuh nyamuk dan nyamuk pernah menghisap darah manusia, yang dapat diketahui dengan adanya kondisi parous (pernah bertelur) pada ovarium nyamuk. Tujuan penelitian ini untuk mengetahui parity rate nyamuk Culex sp., prevalensi nyamuk Culex sp. yang terinfeksi mikrofilaria, prevalensi penduduk Desa Dukuhturi yang terinfeksi mikrofilaria, dan kepadatan mikrofilaria pada penduduk yang terinfeksi mikrofilaria.Penelitian ini dilakukan dengan menggunakan metode survei dengan pengambilan sampel secara cluster random sampling. Data yang diperoleh dianalisis secara deskriptif berdasarkan parousitas nyamuk, keberadaan mikrofilaria pada darah tepi manusia dan nyamuk di Desa Dukuhturi, serta kepadatan mikrofilaria pada sampel darah tepi yang terinfeksi mikrofilaria. Hasil penelitian menunjukan bahwa tingkat parousitas nyamuk Culex sp. tinggi yaitu 94,45\% tetapi prevalensi nyamuk Culex sp. dan penduduk Desa Dukuhturi yang terinfeksi mikrofilaria adalah $0 \%$, sehingga kepadatan mikrofilaria adalah 0.
\end{abstract}

Kata kunci : filariasis, parousitas, prevalensi, kepadatan mikrofilaria.

\section{Pendahuluan}

Filariasis limfatik atau penyakit kaki gajah merupakan penyakit yang banyak ditemukan di wilayah tropis di seluruh dunia. Penyakit ini disebabkan oleh infeksi cacing filaria melalui nyamuk vektor yang hidup dalam kelenjar limfa dan saluran limfa manusia (Chadijah et al., 2014). Insekta yang dapat bertindak sebagai vektor filariasis adalah Anopheles, Aedes, Mansonia, Culex, Simulium, Chrysops dan Culicoides, tergantung spesiesnya (Natadisastra dan Agoes, 2009). Penyakit ini bukan termasuk penyakit infeksi yang menimbulkan kematian, namun bila penderita tidak mendapatkan pengobatandapat menimbulkan cacat menetap. Kecacatan khas yang timbul meliputi pembesaran anggota gerak yang diserangnya seperti tungkai, tangan, kaki, glandula mammae dan skrotum yang berlangsung seumur hidup, sehingga menimbulkan stigma 
sosial bagi penderita dan keluarganya (Brooker, 1997).

Jenis-jenis cacing filaria adalah Wuchereria bancrofti, Brugia malayi, Brugia timori, Loa loa, Onchocerca volvulus, Acanthocheilonema perstans, dan Mansonella azzardi (Natadisastra dan Agoes, 2009). Dari beberapa jenis filaria tersebut, $W$. bancrofti mendominasi hampir $90 \%$ infeksi di dunia, $9 \%$ oleh $B$. malayi di bagian tenggara dan timur Asia, dan $1 \%$ infeksi dari $B$. timori di daerah Pasifik (WHO, 2001 dalam Safitri et al. 2012). Ferlianti (2012) menyebutkan bahwa filariasis bancrofti banyak diderita oleh penduduk di Sub Sahara Afrika, Karibia, Amerika Selatan, Pasifik bagian Barat dan Asia Tenggara termasuk Indonesia.

Menurut Safitri et al. (2012) Indonesia merupakan tempat yang mendukung bagi perkembangan penyakit filariasis karena beriklim tropis.Daerah tropis merupakan tempat yang baik bagi perkembangan cacing filaria dan nyamuk sebagai vektor filariasis, yaitu pada temperatur \pm $27{ }^{\circ} \mathrm{C}$ (Rowley dan Grahan, 1968 dalam Ikhsan, 2014). Filariasis limfatik di Indonesia hanya disebabkan oleh tiga spesies cacing filaria yaitu W. bancrofti, B.malayi, dan B.timori (Santoso dan Suryaningtyas, 2015). Filariasis yang disebabkan olehW.bancroftimempunyai penyebaran paling luas di Pulau Jawa, Bali, Nusa Tenggara dan Papua (Ferlianti et al., 2012).

Menurut Behrman et al. (1996), larva filaria masuk ke dalam tubuh manusia melalui gigitan nyamuk vektor. Masa pertumbuhan mikrofilaria di dalam vektor sampai 2 minggu, sedangkan pada manusia belum diketahui secara pasti, tetapi diduga sampai 7 bulan yaitu sama dengan pertumbuhan cacing filaria pada lutung (Susanto et. al., 2008). Menurut Chandra (2007) cacing filaria betina akan memproduksi mikrofilaria yang masuk ke dalam aliran darah perifer manusia pada malam hari dengan konsentrasi tinggi pada pukul 22.00 sampai pukul 02.00. Saat nyamuk betina menghisap darah penderita filariasis, mikrofilaria stadium I masuk ke tubuh nyamuk akan melepaskan sarungnya di dalam lambung kemudian menembus dinding lambung. Setelah mengalami pertumbuhan menjadi mikrofilaria stadium III yang bergerak aktif.Mikrofilaria tersebut mula-mula berpindah ke rongga abdomen kemudian ke kepala, kelenjar ludah dan alat tusuk nyamuk (Proboscis) (Susanto et. al., 2008). Jika nyamuk tersebut menggigit orang lain, maka mikrofilaria akan masuk ke dalam aliran darah orang yang digigit dan akan berubah menjadi cacing dewasa.

Provinsi Jawa Tengah termasuk dalam propinsi yang terbanyak ditemukan kasus filariasis (Amelia, 2014). Berdasarkan database kesehatan per provinsi, jumlah penderita filariasis di Jawa Tegah dari tahun 2011 sampai 2013 tidak mengalami penurunan yaitu 412 penderita, sedangkan pada tahun 2014 mengalami peningkatan dengan ditemukan 590 kasus (Dinas Kesehatan Provinsi Jawa Tengah, 2014). Lobo et al. (2014) menyatakan bahwa filariasis yang terjadi di beberapa kota di Jawa Tengah seperti Pekalongan dan Semarang disebabkan oleh $W$. bancrofti. Filariasis bancrofti di daerah perkotaan ditularkan oleh nyamuk Culex, sedangkan di pedesaan ditularkan oleh Anopheles dan Aedes (Susanto et. al., 2008).Indriyati et al. (2013) menambahkan bahwa Culex dilaporkan sebagai vektor filariasis bancrofti di Kabupaten Pekalongan Jawa Tengah.

Brebes merupakan salah satu kabupaten dengan kasus filariasis di Jawa Tengah. Berdasarkan Profil kesehatan Kab/Kota (2014), di Kabupaten Brebes terdapat 23 kasus filariasis yang terdiri dari 8 penderita laki-laki dan 15 penderita perempuan. Kasus tersebut tersebar di 20 Desa di Kabupaten Brebes. Salah satu kasus filariasis tersebut ditemukan di Desa Dukuhturi, Kecamatan Bumiayu, Kabupaten Brebes. Desa tersebut belum pernah dilakukan survei filariasis dan pengobatan masal terhadap filariasis (Dinkes Jateng, 2014). Desa Dukuhturi memiliki luas derah $2,96 \mathrm{~km}^{2}$ dengan jumlah penduduk 10.267 jiwa yang terdiri dari 5.091 laki-laki dan 5.170 perempuan. Berdasarkan angka tersebut, maka kepadatan penduduk Desa Dukuhturi adalah $3.467 \mathrm{jiwa} / \mathrm{km}^{2}$ (Daryanto, 2016). Berdasarkan kasus filariasis yang terjadi di Desa Dukuhturi, Kecamatan Bumiayu, Kabupaten Brebes tersebut, maka perlu dilakukan survei darah terhadap penduduk Desa Dukuhturi, Kecamatan Bumiayu, Kabupaten Brebes sebagai langkah awal untuk penentuan microfilaria rate ( $\mathrm{mf}$ rate).

Selain survei darah pada penduduk juga perlu dilakukan survei terhadap nyamuk Culex sebagai vektor filariasis. Perilaku nyamuk vektor dapat berpotensi sebagai penyebar infeksi filariasis(Susanto et. al., 2008). Survei terhadap nyamuk diantaranya melalui pengamatan parousitas untuk mengetahui apakah nyamuk pernah menghisap darah manusia atau belum dan pengamatan infection rate (Mf rate) nyamuk Culex yang terinfeksi filariasis.

Berdasarkan daur hidup cacing filaria, diketahui bahwa hanya nyamuk betina yang menghisap darah. Pada dasarnya nyamuk jantan dan betina menghisap nektar dan cairan lain yang diperlukan untuk tumbuh dan sebagai sumber nutrisinya (Dharmawan, 1993). Namun nyamuk betina akan menghisap darah untuk mematangkan telurnya (Susanto et al., 2008). Oleh karena itu, nyamuk betina yang pernah bertelur mempunyai potensi sebagai penular penyakit filariasis jika pernah menghisap darah penderita.

Dalam penelitian ini dilakukan pengamatan parousitas. Parousitas merupakan suatu parameter untuk mengetahui apakah nyamuk 
pernah bertelur atau belum dengan cara pembedahan ovarium pada nyamuk betina yang merupakan tempat produksi telur. Apabila nyamuk tersebut parous (sudah pernah bertelur) menunjukkan bahwa nyamuk telah menghisap darah manusia dan berpotensi menjadi vektor penyakit filariasis.Nyamuk yang belum pernah bertelur (nulliparous) menunjukkan bahwa nyamuk belum menghisap darah manusia (Marjuki, 2005).

Tujuan penelitian ini adalah: (1) Mengetahui persentase nyamuk Culex betina yang pernah bertelur (parous). (2) Mengetahui prevalensi nyamuk di Desa Dukuhturi, Kecamatan Bumiayu, Kabupaten Brebes yang positif mengandung filaria. (3) Mengetahui prevalensi darah penduduk Desa Dukuhturi, Kecamatan Bumiayu, Kabupaten Brebes yang terinfeksi mikrofilaria. (4) Mengetahui kepadatan mikrofilaria pada sampel positif dari darah penduduk Desa Dukuhturi, Kecamatan Bumiayu, Kabupaten Brebes.

\section{Metode}

Pengambilan Sampel dilakukan di Desa Dukuhturi, Kecamatan Bumiayu, Kabupaten Brebes selama 1 bulan, yaitu Agustus - Oktober 2016. Analisis sampel dilaksanakan di Laboratorium Pengajaran I Fakultas Biologi Universitas Jenderal Soedirman.

Sampel dikoleksi dengan menggunakann teknik cluster random sampling, dimulai dengan memilih 1/3 RW dari $6 \mathrm{RW}$ di Desa Dukuhturi yaitu RW 1 dan RW 3. Masing-masing RW dipilih $1 / 2$ dari 6 RT untuk lokasi pengambilan sampel, sehingga terdapa 6 RT yang dipilih untuk tempat pengambilan sampel.

Pengambilan sampel nyamuk Culex dan darah penduduk dilakukan pada pukul 20.0023.00 WIB.Nyamuk Culex betina ditangkap di lingkungan responden dengan metode Man Biting Rate dan Trap Collection baik di dalam atau di luar rumah. Pengambilan sampel darah penduduk dilakukan berdasarkan ethical clearance dan informed concent. Jumlah sampel darah yang diambil dari penduduk di Desa Dukuhturi, Kecamatan Bumiayu, Kabupaten Brebes sebanyak 30 sampel (orang). Penentuan angka tersebut berdasarkan ketentuan minimum dalam pengambilan sampel (Roscoe, 1975; dalam Sekaran, 2007).

Kriteria inklusi sampel darah manusia: a) Subyek laki-laki atau perempuan > 6 tahun. b) Penduduk Desa Dukuhturi, Kecamatan Bumiayu, Kabupaten Brebes. c) Bersedia menandatangani informed consent bagi subyek dewasa atau diwakilkan orang tua / wali bagi subyek pasien pediatric.

Kriteria eksklusi sampel darah jari: a) Subyek laki-laki atau perempuan < 6 tahun. b) Bukan penduduk Desa Dukuhturi, Kecamatan
Bumiayu, Kabupaten Brebes. c) Tidak bersedia menandatangani informed consent.

Variabel yang diamati pada penelitian ini adalah parousitas nyamuk Culex sp., prevalensi nyamuk Culex sp. yang terinfeksi mikrofilaria, prevalensi penduduk Desa Dukuhturi yang terinfeksi mikrofilaria, dan kepadatan mikrofilaria pada sampel darah penduduk Desa Dukuhturi yang terdapat mikrofilaria. Parameter yang diamati adalah jumlah nyamuk Culex sp. betina yang parous dan nulliparous, jumlah nyamuk Culex sp. yang terinfeksi mikrofilaria, jumlah penduduk Desa Dukuhturi yang terinfeksi mikrofilaria, dan kepadatan mikrofilaria pada sampel darah positif.

\section{Cara kerja}

\section{Survei dan pengamatan terhadap nyamuk}

Penangkapan nyamuk dilakukan 2 kali di sekitar subyek mulai dari jam 20.00-23.00 WIB dengan menggunakan BG-Sentinel Trap dan aspirator. Nyamuk yang tertangkap kemudian dipindahkan ke dalam paper cup yang telah ditutup menggunakan kain kasa berlubang dan karet sebagai tempat pemeliharaan sementara (World Health Organization, 1975).

Nyamuk yang akan dibedah diberi dietil eter sampai pingsan atau mati. Nyamuk yang telah pingsan kemudian diletakkan di atas object glass yang telah ditetesi $\mathrm{NaCl}$ fisiologis. Pembedahan ovarium dilakukan menggunakan mikroskop stereo dengan cara menggunakan jarum bedah ditangan kiri yang ditusukkan pada bagian bawah thoraks dan jarum di tangan kanan ditusukkan diantara segmen abdomen ke 6 dan 7 pada abdomen kemudian ditarik agar kantong ovarium dapat keluar (World Health Organization, 1975). Object glass dipindahkan di bawah mikroskop cahaya untuk melihat parousitas pada ovarium. Hasil yang diperoleh kemudian didokumentasikan. Nyamuk tersebut kemudian dibedah pada setiap bagian tubuhnya dengan bantuan mikroskop stereo.Setelah itu, nyamuk dipindahkan di bawah lensa mikroskop cahaya untuk mengamati keberadaan cacing filaria.

\section{Survei Darah Jari (SDJ)}

Sebelum pengambilan darah dilakukan, jari responden diusap dengan tissue beralkohol. Ujung jari responden ditusuk menggunakan blood lancet kemudian darah pertama yang keluar diusap menggunakan kapas kering. Darah berikutnya dihisap menggunakan mikrohematokrit tanpa heparin sebanyak $\pm 20 \mu \mathrm{l}$.

Darah dipindahkan ke object glass yang telah dibersihkan. Sediaan darah tebal dibuat dengan cara darah pada object glass dilebarkan membentuk bulatan oval $\pm 2 \mathrm{~cm}$ secara perlahanlahan untuk menghindari terputusnya tubuh mikrofilaria (jika ada) (Garjito et al., 2013). 
Sediaan darah yang telah mengering dihemolisa menggunakan air selama 10 menit kemudian dikeringkan. Sediaan darah tersebut difiksasi menggunakan methanol absolut dan dikeringkan. Pewarnaan dilakukan dengan campuran giemsa stok 1 tetes dan 20 tetes buffer dengan lama pewarnaan selama 30 menit, kemudian dibilas dengan air secara perlahan dan dikeringkan (Garjito et al., 2013).

Sediaan Darah yang sudah diwarnai kemudian diamati menggunakan mikroskop cahaya. hasil pemeriksaan dicatat sebagai data pengamatan untuk perhitungan $\mathrm{Mf}$ rate. Microfilaria rate dihitung dengan cara membagi jumlah sediaan yang positif mikrofilaria dengan jumlah sediaan darah yang diperiksa dikali seratus persen (Wahyono et al., 2010).

Hasil positif dari pengujian tersebut kemudian digunakan sebagai data perhitungan kepadatan mikrofilaria pada darah manusia.Jumlah mikrofilaria dihitung dan dicatat sebagai data.Kepadatan rata-rata mikrofilaria adalah angka rata-rata mikrofilaria per $\mathrm{ml}$ darah.

Data yang diperoleh dianalisis secara deskriptif berdasarkan parity rate nyamuk, keberadaan mikrofilaria dan sebagai data perhitungan $\mathrm{Mf}$ rate dan kepadatan rata-rata mikrofilaria.

\section{Hasil dan Pembahasan}

\section{A. Jumlah nyamuk Culex sp. Betina}

Berdasarkan hasil identifikasi terhadap 56 ekor nyamuk yang tertangkap di 6 lokasi di Desa Dukuhturi Kecamatan Bumiayu Kabupaten Brebes, ditemukan 18 ekor nyamuk Culex sp. betina. Masing-masing lokasi pengambilan terdapat nyamuk Culex sp. betina dengan jumlah yang berbeda (Tabel 1.).

Tabel 1. Jumlah nyamuk Culex betina yang tertangkap di sekitar rumah responden di Desa Dukuhturi, Kecamatan Bumiayu, Kabupaten Brebes.

\begin{tabular}{ccc}
\hline Plot & $\begin{array}{c}\text { Total nyamuk } \\
\text { yang tertangkap }\end{array}$ & $\begin{array}{c}\text { Jumlah nyamuk } \\
\text { Culex sp. betina }\end{array}$ \\
\hline I & 6 & 1 \\
II & 8 & 2 \\
III & 13 & 5 \\
IV & 12 & 5 \\
V & 10 & 3 \\
VI & 7 & 2 \\
\hline Total & 56 & 18 \\
\hline
\end{tabular}

Jumlah nyamuk Culex yang ditemukan hanya $32,14 \%$ dari total nyamuk tertangkap kemungkinan karena dipengaruhi oleh beberapa faktor, diantaranya adalah faktor iklim dan lingkungan. Waktu penangkapan nyamuk adalah awal musim hujan dan sering terjadi hujan.
Jumlah nyamuk yang sedikit karena hujan yang turun secara deras akan mengakibatkan telur, larva, pupa nyamuk menjadi hanyut dan nyamuk yang ditemukan sangat sedikit. Menurut McMichael dan Woodruff (2008) dalam Ikhsan (2014), perubahan iklim seperti cuaca dan curah hujan dapat mempengaruhi dinamika biologi dan populasi dari nyamuk.Jika curah hujan berlebihan, maka dapat menyapu tempat perkembangbiakan nyamuk sehingga banyak telur, larva, dan pupa terbawa oleh arus air. $\mathrm{Ba}$ et al. (2005) menambahkan bahwa kelimpahan Culex meningkat secara bertahap selama musim hujan dan mencapai maksimum pada akhir musim hujan.

Kondisi pemukiman di Desa Dukuhturi, Kecamatan Bumiayu, Kabupaten Brebes memiliki tata letak perumahan yang saling berimpitan dan jarang ditemukan halaman luas, sedikit pohon, dan jarang terdapat selokan terbuka. Sari-sari pada tumbuhan merupakan sumber pakan bagi nyamuk untuk kelangsungan hidupnya. Jika sumber pakan tidak tersedia maka nyamuk yang ditemukan tidak banyak. Selain itu, jarang dijumpai genangan air di sekitar perumahan penduduk yang merupakan tempat perkembangbiakan nyamuk, sehingga nyamuk yang ditemukan sedikit. Menurut Islamiyah et al. (2013), kawasan pemukiman dengan keberadaan semak (vegetasi) yang rimbun, lahan perkebunan, kandang ternak, selokan, dan bantaran sungai adalah lingkungan yang mendukung perkembangan nyamuk.

\section{B. Parousitas nyamuk Culex sp. betina yang tertangkap}

Berdasarkan hasil pembedahan ovarium terdapat 17 ekor nyamuk Culex sp. betina yang pernah bertelur (Parous) dan 1 ekor nyamuk Culex sp. betina yng belum pernah bertelur (nulliparous) (Tabel 2.)

Tabel 2. Jumlah nyamuk Culex betina hasil koleksi di Desa Dukuhturi, Kecamatan Bumiayu, Kabupaten Brebes.

\begin{tabular}{cccc}
\hline Plot & $\begin{array}{c}\text { Jumlah } \\
\text { Nyamuk } \\
\text { Culex } \\
\text { Betina }\end{array}$ & $\begin{array}{c}\text { Nulliparous } \\
\text { (Belum } \\
\text { Pernah } \\
\text { Bertelur) }\end{array}$ & $\begin{array}{c}\text { Parous } \\
\text { (Pernah } \\
\text { Bertelur) }\end{array}$ \\
\hline I & 1 & 0 & 1 \\
II & 2 & 0 & 2 \\
III & 5 & 1 & 4 \\
\hline IV & 5 & 0 & 5 \\
V & 3 & 0 & 3 \\
VI & 2 & 0 & 2 \\
\hline Total & 18 & 1 & 17 \\
\hline
\end{tabular}

Berdasarkan hasil yang diperoleh, angka parity rate nyamuk Culex sp. betina di Desa 
Dukuhturi, Kecamatan Bumiayu, Kabupaten Brebes cukup tinggi yaitu $94 \%$. Jumlah nyamuk parous lebih dominan dibandingkan dengan nulliparous akan dapat meningkatkan peluang penyebaran filariasis. Menurut Plichart et al. (2006) jika jumlah nyamuk parous lebih dominan daripada nyamuk nulliparous, maka dapat meningkatkan peluang penyebaran mikrofilaria.

Parousitas adalah kondisi ovarium nyamuk untuk menentukan parous (sudah pernah) bertelur atau nulliparous (belum pernah bertelur) yang dapat diketahui dengan cara membedah ovariumnya (Ndoen et al., 2012). Meskipun pengambilan sampel dilakukan saat musim hujan dan jumlah nyamuk Culex yang tertangkap sedikit, tetapi sebagian besar nyamuk yang ditemukan dalam keadaan parous. Hal tersebut bertentangan dengan pendapat Mbida et al. (2016) yang menyatakan bahwa jumlah nyamuk parous lebih banyak dijumpai saat musim kemarau.Parousitas tinggi pada awal musim hujan dapat terjadi apabila umur nyamuk tersebut tua, sehingga telah mengalami beberapa kali bertelur. Menurut Uttah et al. (2013), meskipun kebanyakan teori menyatakan bahwa jumlah nyamuk parous lebih banyak pada musim kemarau, akan tetapi jumlah nyamuk parous yang banyak pada musim hujan dapat terjadi. Ada kalanya nyamuk dewasa melimpah selama musim kemarau dibandingkan dengan musim hujan. Hal tersebut juga terjadi di Brazil, dimana proporsi nyamuk betina nulliparous lebih tinggi selama musim kemarau, sedangkan nyamuk betina gravid lebih tinggi pada musim hujan (David et al, 2012 dalam Uttah et al., 2013).

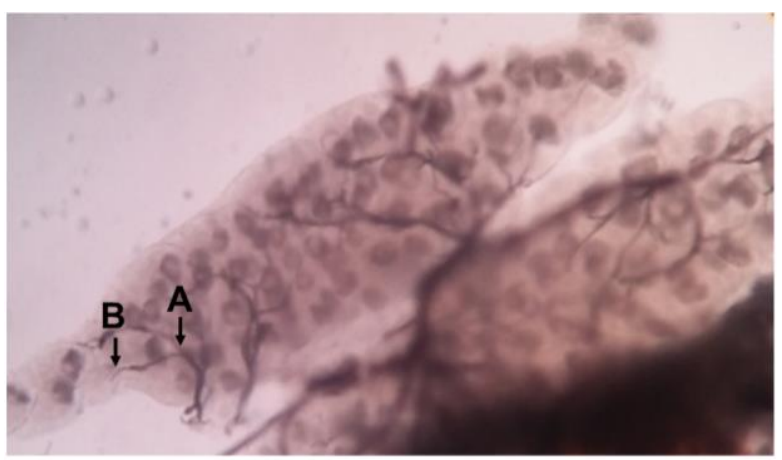

Gambar 1. Ovarium Nyamuk Culex sp Betina parous dengan Perbesaran Mikroskop 10x10.(a) Trachea (b) Tracheolar telah terurai.

Identifikasi nyamuk Culex sp. betina parous dapat diketahui dari keberadan tracheolar yang tidak menggulung pada ovarium (Gambar 1.). Nyamuk Culex sp. betina yang nulliparous ditandai dengan keberadaan tracheolar yang menggulung pada ovarium (Gambar 2.).



Gambar 2. Ovarium Nyamuk Culex sp Betina nulliparous dengan Perbesaran Mikroskop 10 x 10. (a) Tracheolar masih menggulung.

\section{Prevalensi nyamuk Culex sp. betina di Desa} Dukuhturi yang mengandung cacing filaria

Nyamuk Culex sp. betina yang parous (pernah bertelur) kemudian dibedah secara keseluruhan untuk mengamati keberadaan mikrofilaria dalam tubuh nyamuk tersebut. Menurut Susanto et al. (2008), nyamuk betina yang sedang bertelur akan menghisap darah untuk mematangkan telurnya. Oleh karena itu, di daerah yang terdapat penyakit filariasis, nyamuk parous mempunyai peluang sebagai vektor filariasis.

Tabel 3. Prevalensi nyamuk Culex sp. di Desa Dukuhturi yang mengandung Mikrofilaria

\begin{tabular}{cccc}
\hline Plot & $\begin{array}{c}\text { Jumlah } \\
\text { Nyamuk } \\
\text { Culex Betina } \\
\text { parous }\end{array}$ & $\begin{array}{c}\text { Nyamuk } \\
\text { Culex sp. } \\
\text { dengan } \\
\text { Mikrofilaria (+) }\end{array}$ & $\begin{array}{c}\text { Prev } \\
\text { alens } \\
\mathrm{i}(\%)\end{array}$ \\
\hline I & 1 & 0 & 0 \\
II & 2 & 0 & 0 \\
III & 4 & 0 & 0 \\
IV & 5 & 0 & 0 \\
V & 3 & 0 & 0 \\
VI & 2 & 0 & 0 \\
\hline Total & 17 & 0 & 0 \\
\hline
\end{tabular}

Berdasarkan pengamatan terhadap pembedahan nyamuk diketahui bahwa tidak ada nyamuk Culex sp. betina yang mengandung cacing filaria (Tabel 3.), sehingga diketahui bahwa prevalensi nyamuk Culex sp. yang terinfeksi mikrofilaria adalah $0 \%$. Hal tersebut dapat terjadi karena nyamuk parous bukanlah indikator bahwa nyamuk tersebut mengandung cacing filaria, tetapi mempunyai potensi_sebagai vektor filariasis karena pernah menghisap darah. Nyamuk akan terinfeksi cacing filaria jika menghisap darah penderita filariasis. Penderita filariasis yang tercatat dalam Profil kesehatan Kab/Kota tahun 2014 telah mendapatkan pengobatan sejak 30 
Desember 2015, sehingga peluang nyamuk mengandung cacing filaria sedikit. Menurut Susanto et al. (2008), manusia yang terinfeksi cacing filaria dapat menjadi sumber infeksi bagi nyamuk dan orang lain.

\section{Prevalensi penduduk Desa Dukuhturi yang terinfeksi mikrofilaria}

Tabel 4. Prevalensi penduduk Desa Dukuhturi yang terinfeksi mikrofilaria

\begin{tabular}{cccc}
\hline Plot & $\begin{array}{c}\text { Jumlah } \\
\text { Subyek }\end{array}$ & $\begin{array}{c}\text { Terdapat } \\
\text { Mikrofilaria } \\
(+)\end{array}$ & $\begin{array}{c}\text { Prevalensi } \\
(\%)\end{array}$ \\
\hline I & 5 & 0 & 0 \\
II & 5 & 0 & 0 \\
III & 5 & 0 & 0 \\
IV & 5 & 0 & 0 \\
V & 5 & 0 & 0 \\
VI & 5 & 0 & 0 \\
\hline Total & 30 & 0 & 0 \\
\hline
\end{tabular}

Berdasarkan pemeriksaan mikroskopis sampel darah tepi 30 penduduk Desa Dukuhturi, Kecamatan Bumiayu, Kabupaten Brebes tidak ada yang terinfeksi mikrofilaria (Tabel 4.). Oleh karena itu, prevalensi penduduk yang terinfeksi mikrofilaria adalah $0 \%$. Dengan demikian dapat diketahui bahwa filariasis di Desa Dukuhturi belum tersebar. Penyebaran infeksi mikrofilaria dipengaruhi oleh beberapa faktor seperti penduduk sebagai hospes, nyamuk sebagai vektor dan keadaan lingkungan.

Penduduk yang telah terinfeksi cacing filaria dapat menjadi sumber infeksi bagi orang lain melalui gigitan nyamuk (Susanto et al., 2008). Menurut informasi dari Dinas Kesehatan Brebes tahun 2015, menyatakan bahwa terdapat satu penderita filariasis di RT 4 RW 1, Desa Dukuhturi, Kecamatan Bumiayu, Kabupaten Brebes. Berdasarkan survei yang telah dilakukan, dapat diketahui bahwa penyakit tersebut belum tersebar ke penduduk lainnya dan telah mendapatkan pengobatan dari Puskesmas Bumiayu. Pengobatan diethylcarbamazine (DEC) dan albendazole terhadap penderita yang dilakukan sejak 30 Desember 2015 sampai 12 Juni 2016 telah mampu membunuh mikrofilaria dalam darah tepi penderita sehingga memperkecil tingkat

\section{Daftar Referensi}

Amelia, R. 2014. Analisis Faktor Risiko Kejadian Penyakit Filariasis. Unnes Journal of Public Health. 3 (1) : 1 - 12.

Ba, Yamar., D. Diallo., C. M. F. Kebe. I. Dia., and M. Diallo. 2005. Aspects of bioecology of two rift valley fever virus vectors in Senegal (West Africa) :Aedes vexans infeksi filariasis di Desa Dukuhturi, Kecamatan Bumiayu, Kabupaten Brebes. Menurut Susanto et al. (2008), diethylcarbamazine (DEC) merupakan obat yang efektif, aman, dan relative murah. Selain itu, DEC $6 \mathrm{mg} / \mathrm{kg}$ berat badan dan albendazole $400 \mathrm{mg}$ adalah obat yang dianjurkan untuk program eleminasi filariasis melalui pengobatan massal di daerah endemis (WHO, 2000).

Selain hospes, faktor nyamuk sebagai vektor dapat mempengaruhi penyebaran filariasis. Nyamuk yang ditemukan dalam jumlah sedikit karena pengambilan sampel dilakukan saat musim hujan sehingga tempat perkembangbiakan nyamuk stadium telur, larva, dan pupa hanyut oleh arus hujan.Selain itu, penduduk Desa Dukuhturi dapat memelihara lingkungannya dengan baik.Kegiatan lomba kebersihan antar RT yang diselenggarakan oleh perangkat desa juga membangkitkan semangat warga untuk selalu menjaga lingkungannya agar tetap bersih sehingga mengurangi tempat perkembangbiakan nyamuk dewasa. Menurut Valiant et al. (2010), nyamuk Culex lebih menyukai air yang kotor seperti genangan air kotor, limbah pembuangan mandi, got (selokan), dan sungai yang penuh sampah.

\section{E. Kepadatan mikrofilaria pada sampel darah} responden yang positif terinfeksi mikrofilaria

Berdasarkan pemeriksaan darah tepi responden secara mikroskopis tidak ditemukan sampel yang terinfeksi mikrofilaria maka kepadatan mikrofilaria tidak dapat dihitung (0).

\section{Simpulan}

Berdasarkan hasil dan pembahasan, diperoleh kesimpulan (1) Persentase nyamuk Culex sp. betina di Desa Dukuhturi, Kecamatan Bumiayu, Kabupaten Brebes yang pernah bertelur (parous) adalah 94\%, (2). Prevalensi nyamuk yang terinfeksi mikrofilaria di Desa Dukuhturi, Kecamatan Bumiayu, Kabupaten Brebes adalah $0 \%$, (3). Prevalensi darah penduduk yang terinfeksi mikrofilaria Desa Dukuhturi, Kecamatan Bumiayu, Kabupaten Brebes adalah 0\% dan (3). Tidak ditemukan mikrofilaria pada darah penduduk Desa Dukuhturi, Kecamatan Bumiayu, Kabupaten Brebes.

and Culex poicilipes (Diptera: Culicidae). Jurnal of Medical Entomology. 42 (5) : 739.

Behrman., Kliegman., dan Arvin N. 1996. IImu Kesehatan Anak Edisi 5. Jakarta: Penerbit Buku Kedokteran EGC. 
Brooker, Christine. 1997. Kamus Saku Keperawatan E/31. Jakarta: Penerbit Buku Kedokteran EGC.

Chadijah, S., N. N. Veridiana., Risti., dan Jastal. 2014. Gambaran Penularan Filariasis Di Provinsi Sulawesi Barat.Buletin Penelitian Kesehatan. 42 (2) : 101-107.

Chandra, Budiman. 2007. Pengantar Kesehatan Lingkungan. Jakarta: Penerbit Buku Kedokteran EGC.

Daryanto. 2016. Kecamatan Bumiayu dalam Angka 2016. Brebes: Badan Pusat Statistik Kabupaten Brebes.

Dharmawan, R. 1993. Metoda Identifikasi Spesies Kembar Nyamuk Anopheles. Surakarta: Sebelas Maret University Press.

Dinkes Provinsi Jawa Tengah. 2014. Buku Profil Kesehatan Provinsi Jawa Tengah Tahun 2014. Semarang: Dinas Kesehatan Provinsi Jateng.

Ferlianti, R., T. Supali., H. Wibowo. 2012. Optimalisasi Real Time PCR untuk Diagnosis Filariasis Bancroti pada Sediaan Hapus Darah Tebal. Jurnal Kedokteran Yarsi. 20 (1) : $14-22$.

Garjito, T. A., Jastal., Rosmini., H. Anastasia., Y. Srikandi., dan Y. Labatjo. 2013. Filariasis dan Beberapa Faktor yang Berhubngan dengan Penularan Di Desa Pangku-Tolole, Kecamatan Ampibabo, Kabupaten Prigi-Mountong, Provinsi Sulawesi Tengah. Jurnal Vektora. 5 (2) : $54-65$.

Ikhsan, M..2014. Keragaman Jenis dan Fluktuasi Kepadatan Nyamuk pada Peternakan Sapi Unit Reproduksi dan Rehabilitasi Institut Pertanian Bogor. Sripsi (Tidak dipublikasikan). Fakultas Kedokteran Hewan. Institut Pertanian Bogor.

Indriyati, L., L. Waris., A. Rahman., dan Juhairiyah. 2013. Epidemiologi Filariasis di Kabupaten Nunukan. Jurnal Epidemiologi dan Penyakit Bersumber Binatang. 4 (4) : 155 - 161.

Islamiyah, M., A. S. Leksono., dan Z. P. Gama. 2013. Distribusi dan Komposisi Nyamuk di Wilayah Mojokerto. Jurnal Biotropika. 1 (2) :80-85.

Lobo, L. T., S. Chadijah., dan Y. N. Tasidjawa. 2014. Gambaran Kadar Hemoglobin Pada Penderita Filariasisn di Desa Polewali, Kecamatan Bambalamotu, Kabupaten Mamuju Utara, Sulawesi Barat. Jurnal Vektor Penyakit. 8 (2) : 61 -66 .
Marzuki.2005. Studi Populasi dan Kapasitas Vektor Demam Berdarah Dengue (DBD) di Daerah Dengan Endemisitas Berbeda. Tesis (Tidak dipublikasikan). Magister IImu Kesehatan Universitas Diponegoro, Semarang.

Mbida, A. M., J. Etang., P. A. Ntonga., A. Talipouo., P. A. Ambene., F. O. Agbo., C. Eboumbou., M. Akogbéto., R. Osse., G. Lehman., W. Ekoko., J. Binyang., D. Tagne., R. Tchoffo., A. Dongmo., and R. Mimpfoundi. 2016. Preliminary investigation on aggressive culicidae fauna and malaria transmission in two wetlands of the Wouri river estuary, Littoral-Cameroon. Journal of Entomology and Zoology Studies. 4 (6) : $105-110$.

Natadisastra, D., dan R. Agoes. 2009. Parasitologi Kedokteran : Ditinjau dari Organ Tubuh Yang Diserang. Jakarta: Penerbit Buku Kedokteran EGC.

Ndoen, E., C. Wild., P. Dale., N. Sipe., dan M. Dale. 2012. Mosquito Longevity, Vektor Capacity, and Malaria Incidence in West Timor and Central Java Indonesia. International Scholarly Research Network.ISRN Public Health.[Online] http://downloads.hindawi.com/journals/is rn.public.health [Acsessed 22 March 2016].

Plichart, C., Y. Sechan, N. Davies., and A. Legrand. 2006. PCR and dissection as tools to monitor filarial infection of Aedespolynesiensis mosquitos in French Polynesia. Filarial Journal. 5 (2) : $1-9$.

Safitri, A., H. Risqhi., dan M. R. Ridha. 2012. Identifikasi Vektor dan Vektor Potensial Filariasis di Kecamatan Tanta, Kabupaten Tabalong. Jurnal Epidemiologi dan Penyakit Bersumber Binatang. 4 (2) : $73-79$.

Santoso dan N. H. Suryaningtyas.2015. Spesies Mikrofilaria pada Penderita Kronis Filariasis Secara Mikroskopis dan Polymerase Chain Reaction (PCR) di Kabupaten Tanjung Jabung Timur.Media Litbangkes. 25 (4) : 249256.

Sekaran, U. 2006. Metode Penelitian Bisnis. Jakarta: Salemba Empat.

Susanto, I., I. S. Ismid., P. K. Sjarifuddin., dan S. Sungkar. 2008. Parasitologi Kedokteran Edisi Keempat. Jakarta: Balai Penerbil FKUI. 
Uttah, E. C., G. N. Wokem., and C. Okonofua. 2013. The abundance and biting patterns of Culex quinquefasciatus say (Culicidae) in the Coastal region of Nigeria. Hindawi Publishing Corporation. ISRN Zoology :1-7.

Valiant, M., S. Soeng., dan S. Tjahjani. 2010. Efek Infusa Daun Pepaya (Carica papaya L.) terhadap Larva Nyamuk Culex sp. Jurnal Kesehatan Masyarakat. 9 (2) :156 - 161 .
Wahyono, T. Y. M., Purwantyastuti., dan T. Supali. 2010. Filariasis di Indonesia. Jakarta: Buletin Jendela Epidemiologi vol 1.

World Healt Organization.1975. Manual On Practical Entomology In Malaria. Geneva: WHO Offset Publication.

World Healt Organization. 2000. Preparing and implementing a national plan to eliminate lymphatic filariasis. Geneva: WHO Offset Publicatio. 